\title{
BACK PAIN AS A FACTOR OF DISABILITY IN WOMEN OVER 50 FROM BIAŁA PODLASKA AND THE SURROUNDING AREAS
}

\section{DOLEGLIWOŚCI BÓLOWE KRĘGOSŁUPA JAKO CZYNNIK NIEPEŁNOSPRAWNOŚCI KOBIET PO 50 ROKU ŻYCIA Z BIAŁEJ PODLASKIEJ I OKOLIC}

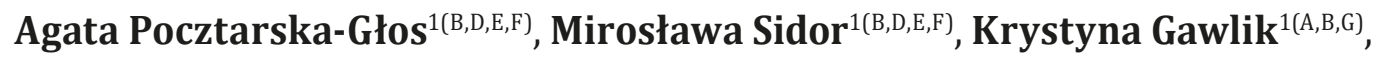 \\ Barbara Bergier $^{1(A, B)}$, Ewa Stępień ${ }^{1(A, B)}$, Joanna Baj-Korpak ${ }^{1(A, B)}$, Adam Szepeluk ${ }^{1(C, D)}$
}

${ }^{1}$ Pope John Paul II State School of Higher Education in Biała Podlaska, Poland

Authors' contribution Wkład autorów: A. Study design/planning zaplanowanie badań B. Data collection/entry zebranie danych

C. Data analysis/statistics dane - analiza i statystyki D. Data interpretation interpretacja danych E. Preparation of manuscript przygotowanie artykułu F. Literature analysis/search wyszukiwanie i analiza literatury G. Funds collection zebranie funduszy
Background. Chronic back pain is one of the most common causes of disability. It is a civilisation disease and up to $75 \%$ of women over the age of 55 suffer from it. The aim of this study was to assess the degree of disability and limitations in the daily functioning of women with lumbar spine pain depending on socio-demographic factors. Material and methods. The study included a group of 274 professionally active women aged between 50 and 64 who come from Biała Podlaska, Poland, and the surrounding areas and who completed the Oswestry Disability Index. The responses showed functional limitations of the respondents during performing specific activities due to back pain. The respondents were characterised with regard to their age, place of residence, education and material status. The results were analysed statistically. Results. The most numerous group included women with moderate disability $-41.6 \%$. Lower back pain intensifies when sitting, standing, walking, lifting objects and applies mainly to women from the oldest age group, women having secondary and lower education, women from the city and those whose financial situation is below the average. Conclusions. A sociodemographic factor that differentiates the degree of the women's disability in a significant way is their material status - the better the financial situation, the less severe the disability. Sociodemographic factors - such as age, education and material status - are strong determinants of functional limitations caused by back pain: women from the oldest age group (60-64 years old) had the biggest problem with walking; women with secondary or lower education experienced difficulty sitting and walking; women whose financial situation is below the average suffered much more difficulties while lifting objects, sitting and socialising.

Keywords: women, back pain, socio-demographic factors, the Oswestry Disability Index

\section{Streszczenie}

Wprowadzenie. Zespoły bólowe kregosłupa sa jedna z najczęstszych przyczyn niepełnosprawności. Należą do chorób cywilizacyjnych i skarży się na nie $75 \%$ kobiet powyżej 55 roku życia. Celem badań była ocena stopnia niepełnosprawności i ograniczeń w codziennym funkcjonowaniu kobiet $\mathrm{z}$ dolegliwościami bólowymi kregosłupa lędźwiowego $\mathrm{w}$ zależności od czynników społeczno-demograficznych. Materiał i metody. Badaniami objęto grupę 274 kobiet aktywnych zawodowo w wieku 50-64 lat z Białej Podlaskiej i okolic, które wypełniły Kwestionariusz Niepełnosprawności Oswestry. Odpowiedzi ukazały ograniczenia funkcjonalne badanych podczas wykonywania poszczególnych czynności na skutek odczuwanego bólu kręgosłupa. Dokonano charakterystyki badanych ze względu na wiek, miejsce zamieszkania, wykształcenie i status materialny. Wyniki poddano analizie statystycznej. Wyniki. Najliczniejszą grupę stanowiły kobiety z niepełnosprawnością w stopniu umiarkowanym - 41,6\%. Dolegliwości bólowe dolnego odcinka kręgosłupa nasilają się podczas: siedzenia, stania, chodzenia, podnoszenia przedmiotów i dotyczą głównie kobiet należących do najstarszej grupy wiekowej, posiadających wykształcenie średnie i niższe, pochodzących z miasta, i których sytuacja finansowa jest na poziomie poniżej przeciętnej. Wnioski. Czynnikiem społeczno-demograficznym, który w istotny sposób różnicuje stopień niepełnosprawności kobiet jest status materialny - im lepsza sytuacja finansowa tym mniejsza niepełnosprawność. Czynniki społeczno-demograficzne - takie jak wiek, wykształcenie i status materialny - są silnymi determinantami ograniczeń funkcjonalnych spowodowanych dolegliwościami bólowymi kręgosłupa: kobiety z najstarszej grupy wieku (60-64 lata), miały najwiekszy problem z chodzeniem; kobiety z wykształceniem średnim lub niższym odczuwały trudności podczas siedzenia i chodzenia; kobiety, których sytuacja materialna jest na poziomie poniżej przeciętnej, odczuwały znacznie większe utrudnienia w podnoszeniu przedmiotów, siedzeniu i prowadzeniu życia towarzyskiego.

Figures: 5

References: 37

Submitted: 2019 Oct 9

Accepted: 2019 Nov 18

Słowa kluczowe: kobiety, bóle kręgosłupa, czynniki społeczno-demograficzne, wskaźnik Oswestry

Pocztarska-Głos A, Sidor M, Gawlik K, Bergier B, Stępień E, Baj-Korpak J, et al. Back pain as a factor of disability in women over 50 from Biała Podlaska and the surrounding areas. Health Prob Civil. 2019; 13(4): 264-272. https://doi.org/10.5114/hpc.2019.89950

Address for correspondence / Adres korespondencyjny: Agata Pocztarska-Głos, Pope John Paul II State School of Higher Education, Sidorska 95/97, 21-500 Biała Podlaska, Poland, e-mail: agata.pocztarska@interia.pl, phone: +48506567 128

ORCID: Agata Pocztarska-Głos https://orcid.org/0000-0002-9834-0016, Mirosława Sidor https://orcid.org/0000-0002-3128-6887,

ORCID: Agata Pocztarska-Głos https://orcid.org/0000-0002-9834-0016, Mirosława Sidor https://orcid.org/0000-00

Barbara Bergier https://orcid.org/0000-0002-9268-4942, Ewa Stępien https://orcid.org/0000-0002-1360-9304,

Copyright: (C) Pope John Paul II State School of Higher Education in Biała Podlaska, Agata Pocztarska-Głos, Mirosława Sidor, Krystyna Gawlik, Barbara Bergier, Ewa Steppień, Joanna Baj-Korpak, Adam Szepeluk. This is an Open Access journal, all articles are distributed under the terms of the Creative Commons AttributionNonCommercial-ShareAlike 4.0 International (CC BY-NC-SA 4.0) License (http://creativecommons.org/licenses/by-nc-sa/4.0/), allowing third parties to copy and redistribute the material in any medium or format and to remix, transform, and build upon the material, provided the original work is properly cited and states its license. 


\section{Introduction}

Low back pain (LBP) syndrome is a serious social problem, which due to its high incidence, is classified as a civilisation disease $[1,2,3]$. Young people complain of low back pain in the lumbosacral spine $[4,5,6]$, and this ailment becomes even more common with age [7, 8]. Research carried out in Poland shows that $72 \%$ of Poles under the age of 40 have experienced spinal pain in the lumbosacral spine at least once in their life [7]. It occurs in approx. $90 \%$ of the population over the age of 40 [9]. The peak incidence falls between the ages of 50 and 60 [10].

Spine pain occurs as a consequence of an incorrect lifestyle associated with stress, low levels of physical activity and a sedentary lifestyle, and often intensifies during activities that increase the load on the spine, e.g. during a prolonged forced flexion position with a rotation component, as a result of axial load on body posture or remaining in a sitting position for a long time. Other predisposing factors resulting in the occurrence of pain are also obesity, micro-injuries of the locomotor system and body posture defects $[11,12,13,14]$.

Lisiński et al. state that there is a lack of unequivocal data proving what type of work (physical, mental) particularly predisposes to pain in the lumbar spine. They stress that overloading of spine structures can be caused by both forms of professional activity requiring high physical exertion, as well as forms often referred to as "sedentary" or "mental" [15]. Lumbosacral back pain syndrome is one of the most common reasons for temporary or long-term inability to work [16, 17]. It also poses restrictions in private and social life [18]. Research indicates that as much as $75.0 \%$ of women over the age of 55 experience chronic back pain in the lumbar spine [7], which limits their daily functioning more than it does in the case of men [19]. In available literature, there are reports on the assessment of the degree of disability according to the Oswestry Disability Index and the associated quality of life of people of different populations, mainly in terms of gender and age. Apart from age, here, the authors focus on understanding the impact of other socio-demographic factors, namely place of residence, level of education, material status, to determine the difficulties in the daily functioning of women with back pain. The aim of the study was to assess the degree of disability resulting from pain in the lumbar spine in women and to answer the following research questions:

1. Do socio-demographic factors differentiate the degree of disability?

2. Do socio-demographic factors condition difficulties in carrying out everyday activities?

\section{Material and methods}

The study was conducted among 274 professionally active women aged between 50 and 64 (the average age was 56.4 \pm 4.3) who come from Biała Podlaska, Poland, and the surrounding areas. All the subjects experienced pain in the lumbar spine. In addition, the criteria for inclusion in the study group were: having good health and no chronic diseases, no spinal injuries or surgical treatment within the spine.

Based on interviews and obtained information on personal data, a division into three age groups was adopted: a) 50 - 54 years old, b) 55 - 59 years old, c) 60 - 64 years old; place of residence (the city, the country), education (secondary and lower, higher) and material status (financial standing below the average, average financial standing, financial standing above the average). The study was anonymous, participation was voluntary with the option of refusing participation at any stage.

Each subject completed the Oswestry Disability Index (ODI) [20], which is a reliable, widely used and recommended criterion for assessing the degree of disability of people with lumbar spine pain syndrome. It contains 10 questions about the intensity of pain and the change in its intensity, and determines the daily functioning of the respondents with respect to lifting objects, walking, sitting, standing, sleeping, self-care, social life, sexual activity, and travelling. For each question, the respondents gave one of six answers defining their condition according to the following scoring: $\mathrm{A}=0 ; \mathrm{B}=1 ; \mathrm{C}=2 ; \mathrm{D}=3 ; \mathrm{E}=4 ; \mathrm{F}=5$. The answers were classified on a scale from 0 to 5 . The aggregate result in the form of point values from 0 to 50 was converted into percentages from 0 to $100 \%$, thus calculating ODI (the Oswestry Disability Index) and determining the degree of disability of the respondents and their functional limitations when performing specific activities. When classifying the severity of disability of each of the women in accordance with ODI [21], the statistical analysis uses Fairbank's interpretation of ODI: (0 - 20\%) - minimal disability, (20 - 40\%) - moderate disability, $(40-60 \%)$ - severe disability, $(60-80 \%)$ - disablement, $(80-100 \%)$ - total disablement - a bedridden person. Statistical calculations were made in STATISTICA v 10. For qualitative variables, a percentage structure (\%) was presented. Pearson's Chi-squared test $\left(\chi^{2}\right)$ was used to detect statistically significant differences. For quantitative variables, arithmetic means were calculated and Mann-Whitney U and Kruskal-Wallis tests were used. The significance value in all the analysed cases was $p=0.05$. 


\section{Results}

Women aged 50-54 - 43.9\%, women living in the city - 61.3\%, women having higher education - 58.0\% and women with an average financial situation $-77.7 \%$ were the majority in the study group. The smallest number of respondents was respondents aged 60-64 - 17.3\%, respondents living in the countryside $-38.7 \%$, respondents having secondary or lower education $-42.0 \%$ and those whose material status is below the average $-6.2 \%$ (Figure 1).

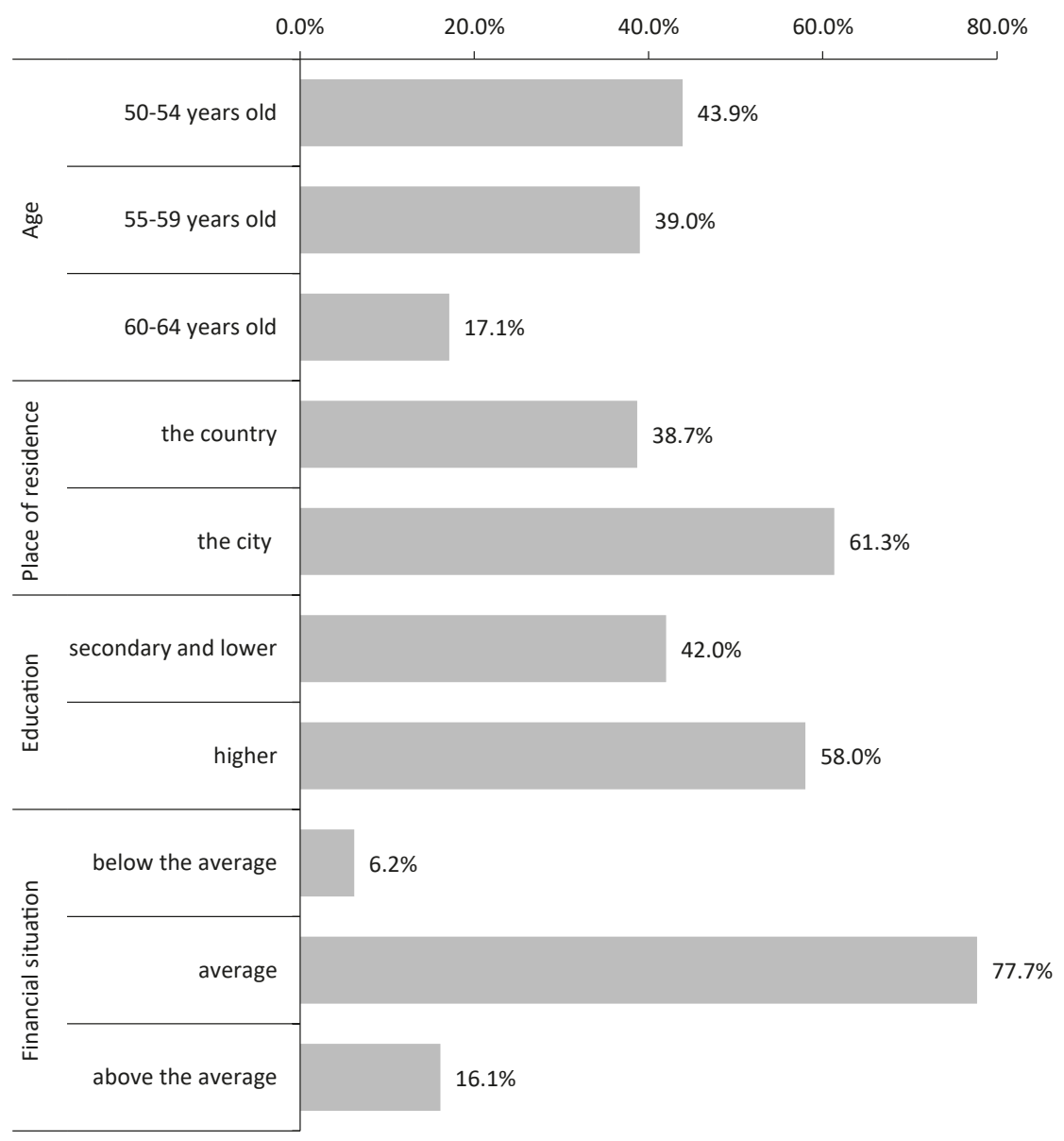

Figure 1. The characteristics of the respondents

The most numerous group of women were respondents with moderate disability - 41.6\%. Minimal disability was found in $28.1 \%$ of the respondents, severe disability in $23.0 \%$, and the highest disability rate, defined as disablement, was presented by $7.3 \%$ of all the respondents. Statistically significant differences were found in the subjective assessment of the degree of disability of the respondents depending on their material status. Among the women with a financial situation above the average, the largest group were those with minimal disabilities $-45.5 \%$. In the group of women with an average financial situation, the most had moderate disability $-44.6 \%$. In contrast, the highest percentage of women with severe (23\%) and a high disability rate (disablement) was in the group of respondents with a financial situation below the average $(p=0.0343)$. In addition, women aged 50-54 were characterised by minimal disability - 31.7\%, respondents living in the city - $29.2 \%$ and university graduates $-28.9 \%$. A moderate degree of disability was evident mainly in older women, respondents aged 55-59 $-44.9 \%$, women from rural areas $-47.2 \%$ and women with higher education $-46.5 \%$. Severe disability was found among the respondents from the oldest age group (60-64 years old) $-27.7 \%$, respondents from the city $-23.8 \%$, respondents with secondary or lower education - 28.7\%. A high level of disability (disablement) was declared by the least respondents and they were mostly the oldest women (60-64 years old) - 10.6\%, respondents from the city $-8.9 \%$, respondents having secondary or lower education $-9.6 \%$ (Figure 2). 


\begin{tabular}{|c|c|c|c|c|c|c|c|}
\hline \multicolumn{2}{|c|}{$0.0 \%$} & $20.0 \%$ & $40.0 \%$ & $60.0 \%$ & $80.0 \%$ & 100. & $0.0 \%$ \\
\hline \multirow{3}{*}{ 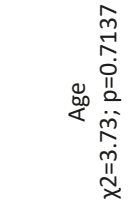 } & 50-54 years old & $31.7 \%$ & \multicolumn{2}{|c|}{$40.8 \%$} & $20.0 \%$ & $7.5 \%$ & \\
\hline & 55-59 years old & $25.2 \%$ & \multicolumn{2}{|c|}{$44.9 \%$} & $24.3 \%$ & 5.6 & $6 \%$ \\
\hline & $60-64$ years old & $25.5 \%$ & \multicolumn{2}{|l|}{$36.2 \%$} & $27.7 \%$ & \multicolumn{2}{|l|}{$10.6 \%$} \\
\hline \multirow{2}{*}{ 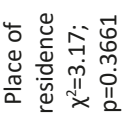 } & country & $26.4 \%$ & \multicolumn{2}{|c|}{$47.2 \%$} & $21.7 \%$ & 4.7 & $7 \%$ \\
\hline & city & $29.2 \%$ & \multicolumn{2}{|c|}{$38.1 \%$} & $23.8 \%$ & \multicolumn{2}{|l|}{$8.9 \%$} \\
\hline \multirow{2}{*}{ 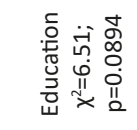 } & secondary and lower & $27.0 \%$ & \multicolumn{2}{|c|}{$34.8 \%$} & $28.7 \%$ & \multicolumn{2}{|l|}{$9.6 \%$} \\
\hline & higher & $28.9 \%$ & \multicolumn{2}{|c|}{$46.5 \%$} & \multicolumn{3}{|c|}{$18.9 \% \quad 5.7 \%$} \\
\hline \multirow{3}{*}{ 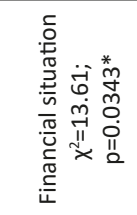 } & below average & $23.5 \%$ & $23.5 \%$ & $35.3 \%$ & & $7.7 \%$ & \\
\hline & average & $24.9 \%$ & \multicolumn{2}{|c|}{$44.6 \%$} & \multicolumn{3}{|c|}{$7.5 \%$} \\
\hline & above average & $45.5 \%$ & & $34.1 \%$ & 18.2 & $2 \%$ & $2.3 \%$ \\
\hline \multicolumn{2}{|l|}{$\begin{array}{l}\overline{\widetilde{\pi}} \\
\stackrel{0}{\circ}\end{array}$} & $28.1 \%$ & \multicolumn{2}{|c|}{$41.6 \%$} & $23.0 \%$ & $7.3 \%$ & \\
\hline
\end{tabular}

$\chi 2-$ Result of the Pearson's Chi-squared test

*significant difference at $\mathrm{p}<0.05$

Figure 2. The degree of disability among the women according to ODI in terms of socio-demographic factors

Age differentiated the respondents significantly in terms of pain sensation and walking difficulties related to it. A significant difference was found between women from the youngest and the oldest age groups. Women aged 60-64 rated their difficulty walking higher $-19.6 \%$ than women aged $50-54-9.0 \%(p=0.0015)$ (Figure 3).

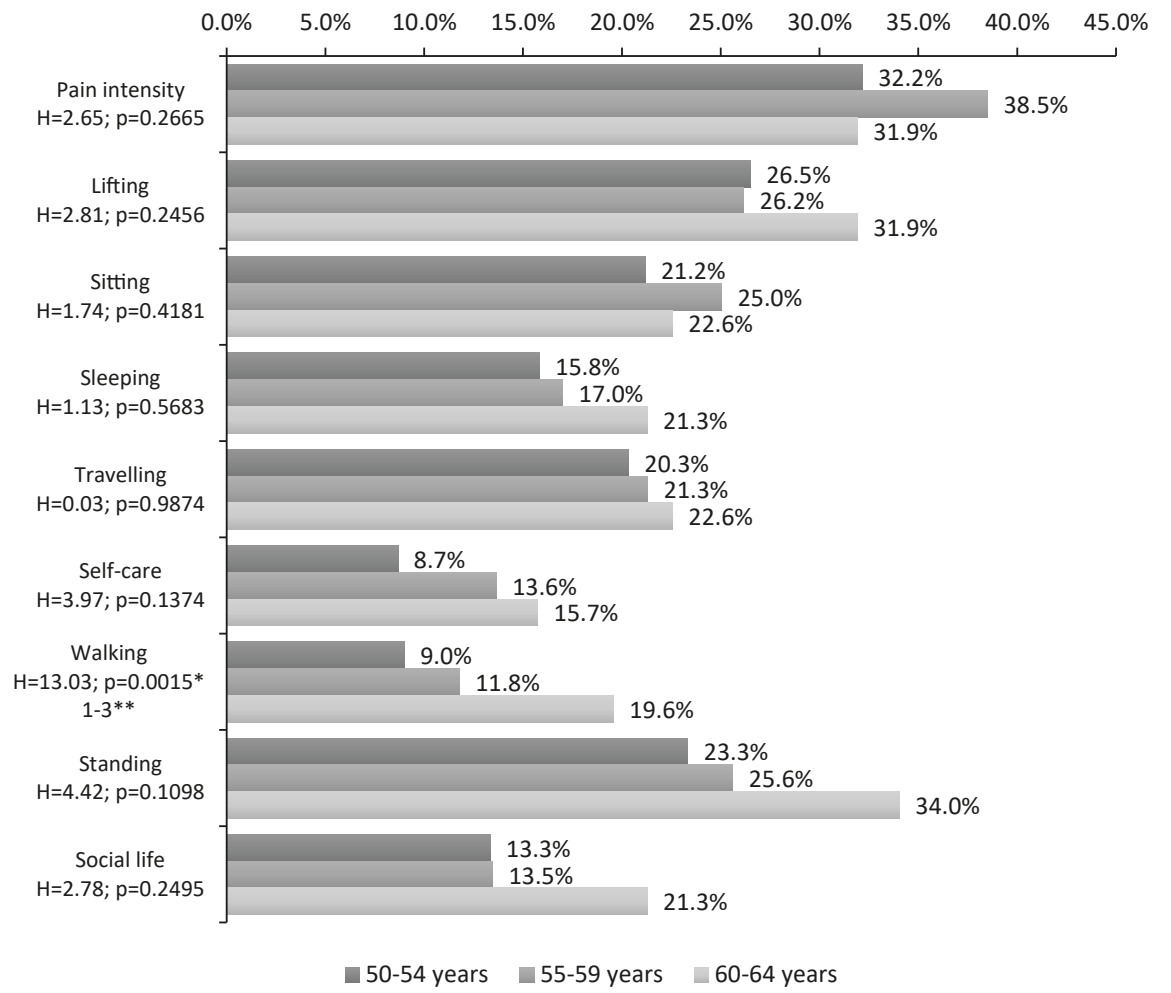

$\mathrm{H}$ - result of the Kruskal-Wallis test;

${ }^{*}$ significant difference at $\mathrm{p}<0.05$; **age groups between which there is statistically significant difference

Figure 3. Functional restrictions caused by pain in the lumbar spine in terms of age 
It turns out that education differentiates the respondents significantly as far as the occurrence of pain during sitting and walking is concerned. Women with secondary or lower education had more difficulty sitting for long periods of time $-26.1 \%$ than women with higher education $-20.6 \%$ ( $p=0.0378$ ). Similarly, women with secondary and lower education admitted that pain in the spine limits their unrestricted movement - 15.7\%, which was indicated by fewer respondents with higher education - 9.2\% ( $p=0.0027$ ) (Figure 4).

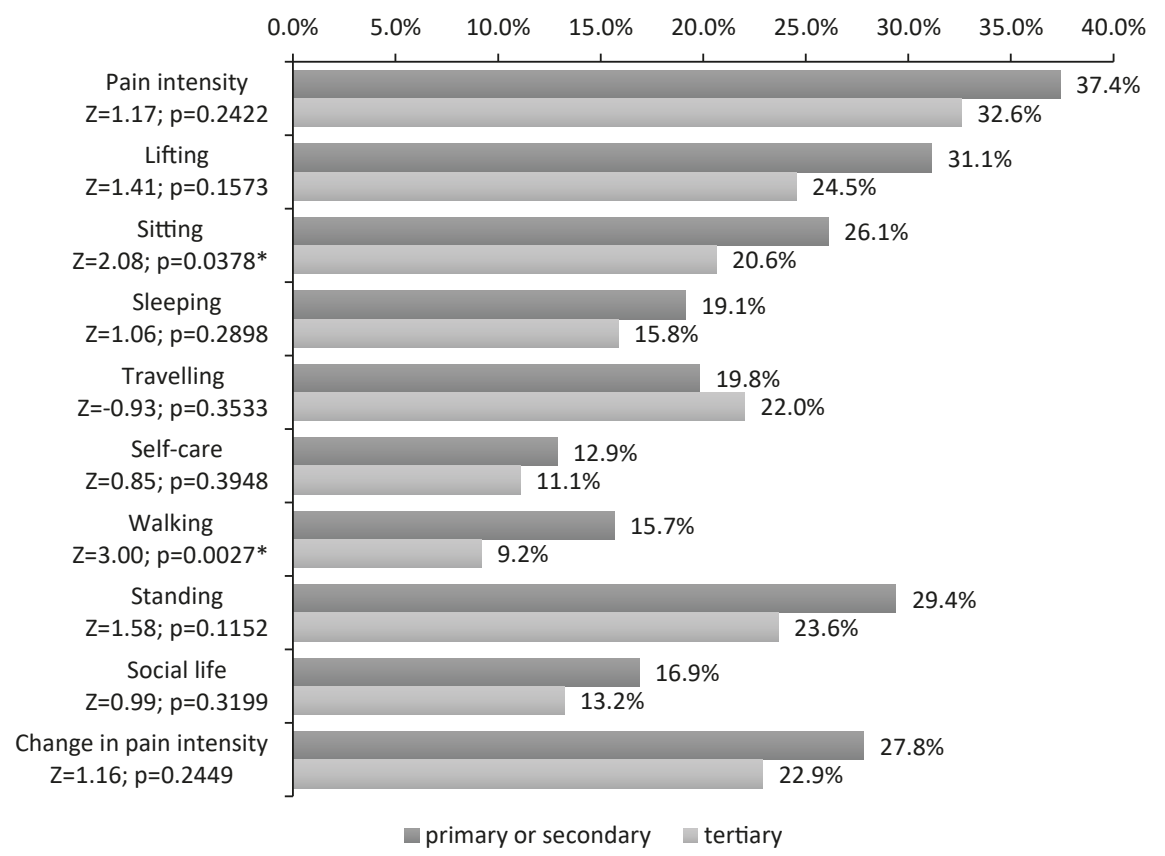

$\mathrm{Z}$ - result of the Mann-Whitney U test

*significant difference at $\mathrm{p}<0.05$

Figure 4. Functional limitations caused by pain in the lumbar spine in terms of education

Material status differentiated the respondents significantly in terms of assessing the degree of disability hindering the performance of the following activities: lifting objects, sitting, socialising and experiencing a change in the intensity of pain. In the case of all of the above-mentioned activities, women declaring their financial standing as being below the average rated the difficulties associated with their functioning the highest. As far as lifting objects is concerned, a statistically significant difference was apparent between women with the lowest material status and women with the highest material status. The former assigned a much higher value $-45.9 \%$ to restrictions connected to this activity than women with the highest material status, who rated this barrier at $21.4 \%(p=0.0201)$. Spine pain prevented women from sitting to a greater extent in the case of women with an average financial position $-35.3 \%$ than the respondents with financial standing above the average who classified this restriction at $15.9 \%$. Furthermore, the pain sensation while sitting were definitely lower in women with the best material status than in women with an average material status $-23.4 \%(p=0.0033)$. Respondents with a below-average financial situation rated the difficulties associated with social life higher $21.2 \%$, in comparison with respondents with an above-average financial situation $-9.5 \%(p=0.0369)$. Similarly, women with a below-average financial situation experienced greater changes in pain intensity - 32.9\% than those with an above-average financial situation $-18.6 \%(p=0.0332)$ (Figure 5). 


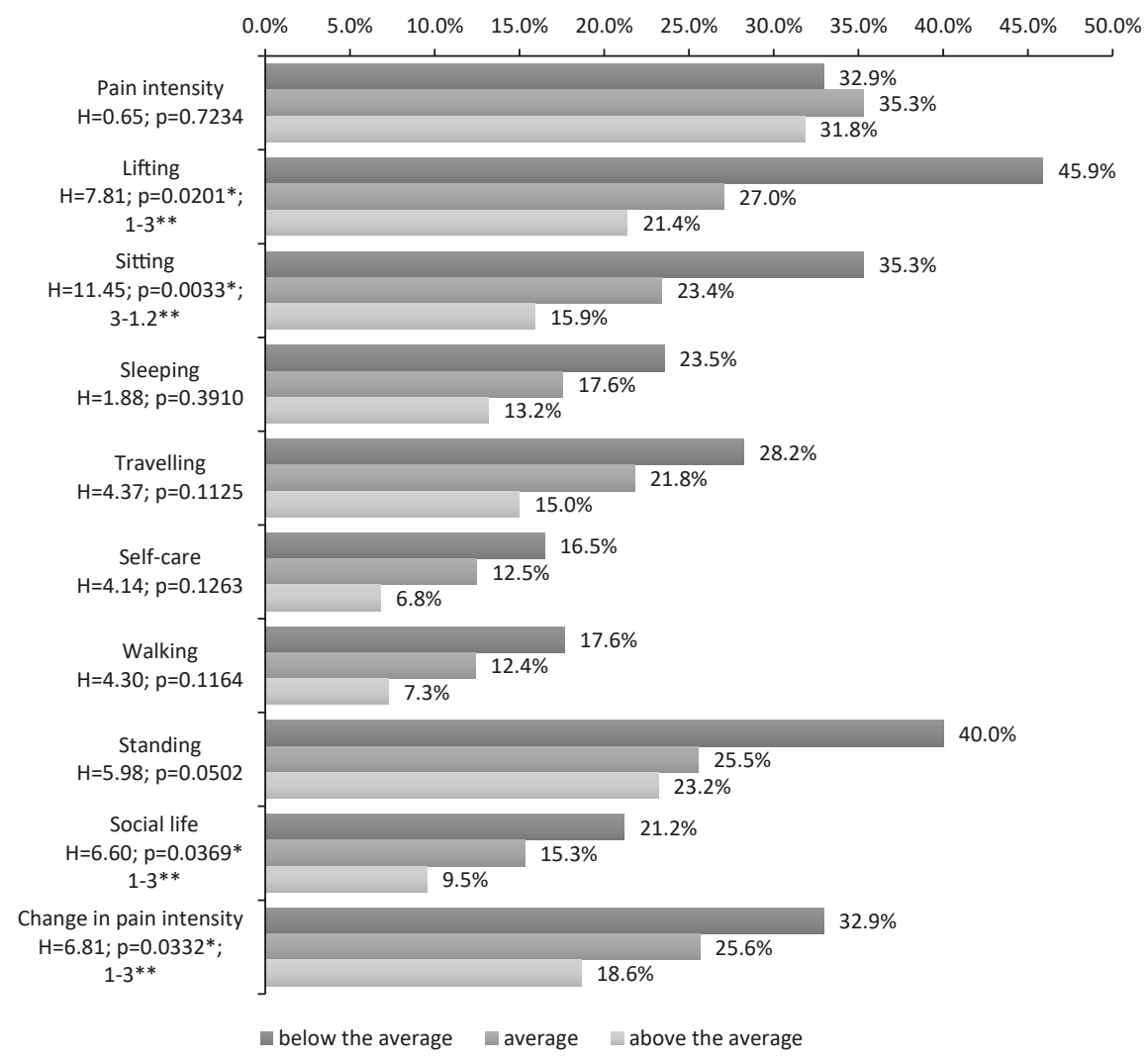

$\mathrm{H}$ - result of the Kruskal-Wallis test

*significant difference at $\mathrm{p}<0.05$; **financial situations between which there is statistically significant difference

Figure 5. Functional limitations caused by pain in the lumbar spine in terms of material status

\section{Discussion}

Pain, referred to as an unpleasant, subjective sensation associated with tissue damage, has a significant impact on the daily functioning of humans [22]. Movement restrictions resulting from the sensation of pain lead to a deterioration in the quality of motor functions and body function. Back pain is a problem of a social nature, the number of people suffering from low back pain syndrome is increasing rapidly [23, 4]. Analyses by Dep et al. confirmed that the indicator that determines the level of disability in people with back pain is age [24]. Their study shows that back pain is very intense during performing particular activities in women aged 60-64. Age predisposes to many diseases, the symptom of which is pain, especially in the musculoskeletal system. Apart from discomfort, pain reduces physical activity and affects basic activities of everyday life in a considerable way. Currently, back pain is an epidemic in societies with a high degree of civilisation development. Lorencowicz and colleagues demonstrated that chronic pain in the lumbar spine disrupts functioning in almost all spheres of life in a significant manner. $60.4 \%$ of nurses were shown to suffer from back pain while sitting for prolonged periods of time [25]. People with low back pain syndrome have problems with daily activities involving bending the torso forwards $[26,27]$. In this study we determined the limitations of daily functioning in the participants. Among the assessed activities, the biggest problem for the respondents was lifting heavy objects, standing, sitting, travelling, sleeping, walking and self-care. Cichońska et al. obtained a similar result confirming that most people have a problem with standing whereas sitting in any position for more than 10 minutes is almost impossible. The pattern is similar in the case of walking and, to a lesser degree, sleeping. Lack of healthy lifestyle habits and knowledge on how to move and lift objects in a correct way causes weakening of the spine, which in turn leads to pain [3]. Our analysis showed that women residing in the city experienced pain more frequently. This is probably related to the type of work that they performed and their lifestyle. Some researchers indicate that study participants usually spend their free time watching TV, listening to the radio, talking to their neighbours and visiting their relatives. Their social life, participation in senior clubs or interest/support groups is also low $[25,28]$. However, Repka and Wordliczek's study shows that the place of residence does not have much influence on the degree of pain and that respondents living in the urban environment felt less pain than people from rural areas [29]. Similarly, studies by Michalika et al. showed a higher number of hospitalisations of adults due to low 
back pain among the inhabitants of rural areas than cities [30]. The authors of other studies have shown that the inhabitants of rural areas assess their health condition more negatively than urban residents. This is associated with additional negative determinants related to more difficult living conditions in the rural environment [31, 32]. The physical nature of work is an important factor contributing to the occurrence of overload changes in the lower spine and the occurrence of pain [33]. Solecki's study showed that farmers experience pain in the lower spine more often than white-collar workers [34].

According to Pędich, the condition of general health also depends on other variables such as education, lifestyle, and environmental factors [32]. Education is another demographic factor that affected the degree of pain sensation. Repka points out that respondents with primary and vocational education experienced the strongest pain [29]. The findings presented here confirm that the intensity of pain, especially when sitting and walking, in the case of women with secondary and lower education is higher than in the case of women with higher education. By contrast, studies by Lee et al. suggest that education plays a limited role in the modification of pain intensity [35]. Gajewski et al. emphasise that people with lower education more often express dissatisfaction with their health, and the level of satisfaction increases with the level of education [36]. Not only does the physiology of the body affect the intensity of pain, but also family and financial situation. That is why the support of loved ones, both emotional and financial, is so important. Treatment of back diseases requires ever-increasing financial outlays. Refunds by the National Health Fund are not sufficient compared with the demand. Patients wait for treatment for several years. Yet, patients who can afford commercial treatment, choose to pay for it [31]. The findings we describe indicate that women whose financial situation was below the average had more difficulty lifting objects and sitting because of back pain than women with high material status. In addition, back pain was a barrier for them to lead a regular social life. The reduction of spinal dysfunction enabling leading a normal family, social and professional life is one of the basic therapeutic and nursing tasks [37, 32]. People are usually happy with their lives, but the factor that reduces life quality is pain, which, according to research studies, occurs very often. Numerous reports emphasise that pain affects the well-being of respondents negatively, hence leading to disorganisation of life [32]. Therefore, it is crucial to educate society about the awareness of the causes of back pain syndrome, methods of treatment and, above all, preventive actions aimed at minimising pain and thus improving the quality of life.

\section{Conclusions}

1. A socio-demographic factor that differentiates the degree of women's disability in a significant manner is their material status - the better the financial situation, the lesser the disability.

2. Socio-demographic factors - such as age, education and material status - are strong determinants of functional restrictions caused by back pain:

- women from the oldest age group (60-64 years old) had a significantly larger problem with walking than the youngest women (50-54 years old);

- women with secondary or lower education had more difficulty sitting and walking than women with higher education;

- women whose material status is above the average were more sensitive to changes in the intensity of pain compared with women whose material status is below the average. They also found socialising and moving objects to be less problematic. Sitting was less onerous than in the case of women with an average or below-average financial situation.

\section{Disclosures and acknowledgements}

The results presented in the paper are part of the research carried out within the framework of the research project entitled "Lifestyle and chosen aspects of physical state of professionally active women aged 50-64 years old" financed with the grant funds for own research at Pope John Paul II State School of Higher Education in Biała Podlaska, Poland.

\section{References:}

1. Nisha J, MacGregor AJ. Epidemiology of back disorders prevalence, risk factors and prognosis. Curr Opin Rheumatol. 2005; 17(2): 134-140.

2. Bjerkreim I, Steen H, Brox JI. Idiopathic scoliosis treated with Cotrel-Dubousset instrumentation: evaluation 10 years after surgery. Spine. 2007; 32(19): 2103-2110. https://doi.org/10.1097/BRS.0b013e318145a54a 
3. Pop T, Przysada G, Świder B. [Disability degree of medical personnel measured by Oswestry Questionnaire]. Przegląd Medyczny Uniwersytetu Rzeszowskiego. 2008; 2: 135-141 (in Polish).

4. Stefanowicz A, Kloc W. [Prevalence of low back pain among students]. Polish Annals of Medicine. 2009; 16(1): 28-41 (in Polish).

5. Kędra A, Czaprowski D. [The prevalence of back pain among schoolchildren aged 13-16 years in Biała Podlaska district]. Kwartalnik Ortopedyczny. 2012; 3: 351-360 (in Polish).

6. Sieradzki M, Krajewska-Kułak E, Van Damme-Ostapowicz K. [Assessment of occurrence of low back pain in the population of physiotherapy students]. Problemy Higieny i Epidemiologii. 2013; 94(3): 451-458 (in Polish).

7. Kołodziej K, Kwolek A, Rusek W, Przysada G, Szpunar P. [Correlation between lower extremities symmetrical index and intensification of lower back pain in patients after hospital rehabilitation]. Przegląd Medyczny Uniwersytetu Rzeszowskiego i Narodowego Instytutu Leków. 2005; 3: 234-236 (in Polish).

8. Śliwiński Z, Śliwa M, Starczyńska M, Kiebzak W. Quality of life in patients with lumbarspinal pain. Fizjoterapia Polska. 2014; 14(2): 26-39.

9. Sapuła R, Głowacka I, Lesiak A, Siwek W, Mataczyński K. [Evaluation of the effectiveness of rehabilitation patients with low back pain]. Zamojskie Studia i Materiały. 2012; 1(35): 1-9 (in Polish).

10. Korabiusz K, Lubkowsk A, Wawryków A. [The review of most commonly used physiotherapy methods in spineaches based on analysis of patient documents in NZOZ ŚROD-MED Police]. Journal of Education, Health and Sport. 2016; 6(4): 127-140 (in Polish).

11. Radziszewski KR. [Functional status of patients with lumbar discopathy being treated exclusively with conservative or surgical procedures]. Wiadomości Lekarskie. 2008; 1(3): $23-29$ (in Polish).

12. Depa A, Drużbicki M. [Assessment of frequency of lumbalgia occurrence with relation to the character of performed work]. Przegląd Medyczny Uniwersytetu Rzeszowskiego. 2008; 1: 34-41 (in Polish).

13. Maciuk M, Krajewska-Kułak E, Klimaszewska K. [Self-assessment of low back pain incidence in professionally active nurses]. Problemy Higieny i Epidemiologii. 2012; 93(4): 728-738 (in Polish).

14. Frymoyer JW, Pope MH, Costnza MC. Epidemiologic studies of low-back pain. Spine. 1980; 5(5): 419-423. https://doi.org/10.1097/00007632-198009000-00005

15. Lisiński P, Majewska M, Samborski W. [Efficiency of muscles strengthening exercises in patients with herniated lumbar intervertebral discs]. Balneologia Polska. 2006; 1: 36-39 (in Polish).

16. Mirovsky Y. Guidelines for the prevention of low back pain. Harefuah. 2007; 146(4): 272-318.

17. Radziszewski KR. [Comparative analysis of professional activity of patients with lumbar discopathy being treated exclusively with conservative or surgical procedures ]. Wiadomości Lekarskie. 2007; 1(2): 15-20 (in Polish).

18. Wójcik A, Martowicz B. [Pain syndromes of the lumbar-sacral regions of the spine]. TH!NK - studenckie naukowe czasopismo internetowe. 2012; 10: 50-63 (in Polish).

19. Bojczuk T, Przysada G, Strzępek Ł. [Influence of therapeutic exercises on quality of life indices in patients with chronic spine pain]. Przegląd Medyczny Uniwersytetu Rzeszowskiego. 2010; 1: 66-72 (in Polish).

20. Fairbank JCT, Pynsent PB. The Oswestry Disability Index. Spine. 2000; 25(22): 2940-2953. https://doi.org/10.1097/00007632-200011150-00017

21. www.rehab.msu.edu [Internet]. East Lansing: Rehabilitation Medicine Clinic, Michigan State University. Oswestry Low Back Pain Disability Questionnaire [cited 2019 May 22].

Available from: http://www.rehab.msu.edu/_files/_docs/oswestry_low_back_disability.pdf

22. Rechcińska-Roślak B, Janiszewski M. [Pain as a problem in physiotherapy]. Medycyna Manualna. 2004; 4: 17-22 (in Polish).

23. Klimaszewska K, Krajewska-Kułak E, Kondzior D, Kowalczuk K, Jankowiak B. [Quality of life in patients with lumbar spine pain syndromes]. Problemy Pielęgniarstwa. 2011; 19(1): 47-54 (in Polish).

24. Depa A, Przysada G, Wolan A. [The degree of functional activity impairment of the patients with low back pain syndrome measured with Oswestry Questionnaire]. Postępy Rehabilitacji. 2010; 24(2): 5-13 (in Polish).

25. Kubińska Z, Bergier B, Bergier J. [Participation of disabled rural and urban inhabitants of the Lublin Region in tourism and recreation]. Medycyna Ogólna i Nauki o Zdrowiu. 2011; 17(46): 189-193 (in Polish).

26. Lorencowicz R, Jasik J, Kołodyńska M, Turowski K. Assessment of the effect of pain on daily functioning of patients with the diagnosed back pain syndrome. The Journal of Neurological and Neurosurgical Nursing. 2014; 3(4): 157-168.

27. Miller B, Gawrońska K, Szczepanowska-Wołowiec B, Lorkowski J, Kotela A, Hładki W, et al. [Quality of life of patients with osteoarthritis within the lumbar spine]. Ostry dyżur. 2016; 3(16): 88-91 (in Polish). 
28. Orzechowska G. [Self-assessment of the activity of the elderly living in rural areas]. In: Solecki L., editor. [Problems of the elderly and the disabled in agriculture]. Lublin: Instytut Medycyny Wsi; 2004. p. 46-52 (in Polish).

29. Repka I, Wordliczek J. [The influence of socio-demographic factors on the intensity of pain, quality of life and its components among patients with chronic pain]. Problemy Pielęgniarstwa. 2013; 21(3): $348-59$ (in Polish).

30. Michalik R, Kowalska M, Kotyla P, Owczarek AJ. [Frequency of hospitalization due to low back pain syndrome in Poland and European countries]. Pomeranian Journal of Life Sciences. 2015; 61(2): $214-219$ (in Polish). https://doi.org/10.21164/pomjlifesci.81

31. Karwat ID, Karski A. [The level of living comfort of the disabled depending on the family and social environment]. In: Solecki L., editor. [Problems of the elderly and the disabled in agriculture]. Lublin: Instytut Medycyny Wsi; 2004. p. 174-185 (in Polish).

32. Pędich W. [Diversity of living conditions and social situation of the elderly in rural areas]. In: Solecki L., editor. [Problems of the elderly and the disabled in agriculture]. Lublin: Instytut Medycyny Wsi; 2004, p. 26-36; 46-52 (in Polish).

33. Czenczek-Lewandowska E, Przysada G, Brotoń K, Leszczak J, Rykała J, Podgórska-Bednarz J. [The influence of rehabilitation on the functional status and pain in patients with spinal overload syndrome]. Przegląd Medyczny Uniwersytetu Rzeszowskiego i Narodowego Instytutu Leków. 2014; 3: 243-252 (in Polish).

34. Solecki L. [Preliminary evaluation of musculoskeletal pain disorders reported by private farmers]. Medycyna Pracy. 2012; 63(3): 281-293 (in Polish).

35. Lee GK, Chronister J, Bishop M. The effects of psychosocial factors on quality of life among individuals with chronic pain. Rehabilitation Counseling Bulletin. 2008; 51(3): 177-189. https://doi.org/10.1177/0034355207311318

36. Gajewski T, Woźnica I, Młynarska M, Ćwikła S, Strzemecka J, Bojar I. [Selected aspects of quality of life of patients with degenerative changes in the spine and joints]. Medycyna Ogólna i Nauki o Zdrowiu. 2013; 19(3): 362-369 (in Polish).

37. Glassman S, Gornet MF, Branch C, Polly DJ, Peloza J, Schwender JD, et al. MOS short form 36 and Oswestry Disability Index outcomes in lumbar fusion: a multicenter experience. The Spine Journal. 2006; 6(1): 21-26. https://doi.org/10.1016/j.spinee.2005.09.004 